\title{
TREBA LI EUROPSKA UNIJA UPRAVNO-POLITIČKI ILI POLITIČKO-UPRAVNI PRISTUP
}

\author{
UDK: 35.07 (4-6 EU) \\ DOI:10.31141/zrpfs.2021.58.141.711 \\ Izvorni znanstveni rad \\ Primljeno: 10. veljače 2021.
}

\begin{abstract}
Rad se bavi dvama različitim koncepcijskim pristupima u razvoju političko-upravnih institucija u kontekstu integracijskih procesa koji se odvijaju u Europskoj uniji - upravno-političkim i političkoupravnim. Polazi se od različitih shvaćanja uloge koju europske integracije imaju po države članice, kako bi se ukazalo na implikacije koje izazivaju različiti pristupi integracijskim procesima na razini Unije. U prvom dijelu istraživanja postavlja se metodološki okvir u kojem se kreće analiza ovih dvaju pristupa i njihov utjecaj na europske integracije. Drugi dio posvećen je analizi rezultata vezanih uz primjenu tih pristupa. Pritom se njihova primjena motri kroz proces konvergencije upravnih sustava država članica, kao i političko-koncepcijske razlike vezane uz njihovu provedbu. U zadnjem dijelu, kroz zaključna razmatranja daje se ocjena ovih pristupa u dosadašnjem razvoju europskih institucija i njihov utjecaj na budući razvoj integracijskih procesa u Europskoj uniji, u svjetlu dinamike odnosa na relaciji države članice - europske institucije.
\end{abstract}

Ključne riječi: Europska unija, političko-upravni pristup, upravno-politički pristup

\section{UVOD}

Predmet analize ovog rada jest pitanje kakav pristup u budućem razvoju europskih institucija Europa treba: upravno-politički ili političko-upravni. Iako na prvi pogled ova dvojba izgleda poput igre riječi koja uključuje slične pojmove koji se međusobno u nekim segmentima i preklapaju, pitanje je zapravo suštinske prirode. Od samih svojih početaka, ideji europskih integracija pristupa se sa dva oprečna stajališta. S jedne strane, postoji shvaćanje o potrebi snažnije institucionalne integracije i konvergencije upravno-političkih sustava država članica. Ova integracija treba završiti izgradnjom zajedničkih europskih upravnih i političkih institucija i stvaranjem europskog regulatornog okvira potrebnog za njihovo uređenje i dalji napredak. Ovakav razvoj treba dovesti do stvaranja europskog naddržavnog poretka, koji uključuje i elemente federacije. Kao razlog oblikovanja ovog tipa integracija ističe se potreba za većom efikasnošću i snažnijom prisutnošću europskih institucija, kako u unutarnjim, tako i u vanjskopolitičkim odnosima Unije. S druge strane,

\footnotetext{
1 Prof. dr. sc. Mirko Klarić, e-mail: mirko.klaric@pravst.hr
} 
postoji i shvaćanje kako je Europska unija u prvom redu savez suverenih europskih država, koje kroz međusobnu suradnju lakše ostvaruju svoje interese i promiču vlastite ciljeve. Zbog toga je sama Unija u prvom redu zajednica suverenih država, a tek potom zajednica ravnopravnih građana s pravima i slobodama koje proizlaze iz zajedničkog europskog projekta. Prema tome, težište u odnosu Unija - države članice prvenstveno je na državama članicama koje određuju tempo i dinamiku međusobne suradnje, kao i intenzitet međusobnih odnosa. Stoga je u međusobnim odnosima naglasak na koordinaciji i usuglašavanju s ciljem postizanja konsenzualnih rješenja, neovisno o tome koliko je kompleksan put koji do njih vodi.

Činjenica je da je dosadašnji razvoj europskih institucija pokazao prednosti i nedostatke i jednog i drugog shvaćanja europskih integracija. Europska unija koja bi u prvom redu bila zajednica država sa zajedničkim institucijama koje nemaju snažnije ovlasti, često nije u stanju ni na unutarnjem, ni na vanjskopolitičkom planu arikulirati dosljedne i konzistentne politike i i ciljeve, zbog različitih interesa koje imaju pojedine države članice, a koje je teško uskladiti. Zbog toga se posebice u vanjskoj politici na Europsku uniju često gleda kao na trgovačkog i gospodarskog diva koji je istovremeno i politički patuljak. S druge strane, povijesni, društveni, politički i gospodarski razvoj europskog kontinenta doveo je do bogate kulturne i društvene diverzifikacije europskih nacija. Zbog toga je pitanje njihove snažnije integracije osjetljivo i kompleksno, jer integracija uključuje i novu regulaciju koja dovodi do ograničenja koja utječu na njihovu samostalnost i političku neovisnost. Kako je javna uprava instrument za provedbu političkih odluka, pitanje institucionalnog okvira ključno je za njezino uspješno funkcioniranje. Bilo kakava promjena u organizacijskoj i institucionalnoj koncepciji upravno-političkog sustava utječe na funkcioniranje uprave kao politički izvršujuće skupine. S druge strane, provedba političkih odluka kao i disfunkcionalnosti u toj provedbi uvijek otvaraju pitanja o reformi postojećeg sustava, kako bi se on u danim političkim i društvenim okolnostima učinio uspješnijim i efikasnijim. Zbog toga je pitanje koncepcije i samog pristupa ono koje u budućnosti determinira dinamiku europskih integracija i razvoj europskih institucija. Kako bi se pojasnile razlike u koncepciji razvoja europskih institucija i Unije kao cjeline, polazi se od različitih shvaćanja europskih integracija, te se u tom svjetlu analiziraju različiti pogledi na budući razvoj europskih institucija, sukladno različitim koncepcijskim pristupima dinamici društvenih, političkih i gospodarskih odnosa unutar same Europske unije.

\section{METODOLOŠKI OKVIR}

Istraživanje obuhvaća analizu različitih pogleda na ideju europskih integracija, koji se u svojoj osnovi mogu svesti na dva temeljna, međusobno oprečna shvaćanja. Prvo je shvaćanje europskih integracija kao procesa ireverzibilne konvergencije različitih europskih država i njihovih političkih, upravnih, gospodarskih i društvenih poredaka. Ova konvergencija postupno vodi k unifikaciji zajedničkih standarda postupanja i funkcioniranja pojedinih država članica i Europske unije kao cjeline. 
Ona nadalje doprinosi izgradnji zajedničkih europskih institucija, koje trebaju osigurati veću efikasnost u obavljanju čitavog niza različitih javnih funkcija, što s druge strane dovodi do postupnog ograničavanja samostalnosti država i njihovih upravno-političkih sustava. S druge strane, postoji i shvaćanje europskih integracija kao izgradnje zajedničkih institucija koje trebaju osigurati obavljanje onih funkcija koje su nužne za međusobnu suradnju država na zajedničkom europskom tržištu. Zbog toga europske institucije imaju isključivo suportivni karakter te ne mogu biti osnova za izgradnju takvog naddržavnog projekta koji će ugroziti samostalnost i suverenost nacionalnih država, a one uvijek mogu svojom odlukom blokirati one procese koji to dovode u pitanje. U analizi ovog problema koristi se metoda deskripcije, komparacije, te uzročno-poljedične analize. Njima se nastoji terminološki raščlaniti postojanje dvaju različitih pristupa europskim integracijama, utvrditi njihove razlike kroz komparativnu analizu te ukazati na uzročno-posljedične veze koje postoje u dinamici razvoja ovih pristupa europskim integracijama. Ovako različit metodološki okvir treba ukazati na dvojbu vezanu uz europske integracije o tome koji bi pristup mogao biti najprimjereniji s obzirom na povijesne, političke, društvene i gospodarske okolnosti u kojima se Europske unija i države članice nalaze.

\section{REZULTATI}

\subsection{Proces integracije u Europi - jedna ideja i različiti pristupi}

Jedno od temeljnih pitanja koje se postavlja prilikom rasprave o budućnosti europskih integracija jest kakav je tip integracije unutar Europske unije, kao zajednice europskih naroda, poželjan i potreban kako bi se osigurala učinkovitost i ekonomičnost funkcioniranja zajedničkih europskih institucija, a istovremeno zadržao veliki stupanj decentralizacije i samostalnosti država članica. ${ }^{2}$ Time se pokušava pomiriti jedno od temeljnih načela Europske unije, načelo supsidijarnosti, sa zahtjevima za funkcionalnošću koji se stavljaju pred zajedničke europske institucije. ${ }^{3}$ Ovo se pitanje provlači od samih početaka europskih integracija i potiče niz diskusija u kojima se u pravilu kristaliziraju dva, međusobno suprotstavljena stajališta. ${ }^{4}$ Jedno uključuje shvaćanje prema kojem države članice trebaju imati visok stupanj samostalnosti, a sami dio nadležnosti potrebnih za obavljanje zajedničkih

2 Usp. Bačić, A.: "EU ante portas i Ustav Republike Hrvatske", Zbornik radova Pravnog fakulteta $u$ Splitu, god. 38, 2001., str. 259-281.

3 Lopatka, R.: "Subsidiarity: Bridging the gap between the ideal and reality", European View, god. 18, br. 1., 2019., str. 26-36.

4 Eichorn, J. - Kenealy, D. - Hübner, C.: "Who wants a referndum on EU membership? Exploring public attitudes in six Member States", Journal of European Integration, Vol. 43, br. 3., 2021., str. 365383 . 
poslova valja prenijeti na zajedničke institucije, sukladno načelu supsidijarnosti. ${ }^{5}$ Drugo pak shvaćanje polazi od toga da je radi globalnih izazova potrebno raditi na koncentričnom jačanju i širenju onih ovlasti koje trebaju osigurati efikasno funkcioniranje zajedničkih europskih institucija. ${ }^{6}$ Iako na prvi pogled slična, ova se dva pristupa značajno razlikuju. Prvo polazi od organizacijskog ustrojstva Unije kao zajednice država. Drugo polazi od organizacijskog ustrojstva Unije kao državne zajednice u kojoj postoji snažnija integracija u onim pitanjima koja su od interesa za sve njezine članice. Ova stajališta dovode do različitih pozicija država članica, ovisno o tome kakvo je njihovo shvaćanje budućeg razvoja europskih integracija. ${ }^{7}$ Ukoliko se europske integracije promatraju isključivo kao tehničko pitanje potpore i oslonca nacionalnim državama, pitanje političke integracije postaje irelevantno za dalji razvoj europskih institucija. Ukoliko se integracije promatraju kao stvaranje zajedničkog europskog kulturnog kruga, utemeljenog na zajedničkim europskim vrijednostima koje prožimaju europske političke i upravne institucije, onda se pitanje političke integracije nameće poželjnim samo po sebi. ${ }^{8}$ Iako s jedne strane globalne ugroze i problemi utječu na stajalište država za pojačanom integracijom, kako bi se s novim izazovima lakše nosile, s druge strane, povijesne okolnosti, političke i društvene tradicije i posebnosti samih država potiču njihov otpor ka stvaranju naddržavnih tvorevina koje će ugroziti njihovu samostalnost i neovisnost. ${ }^{9}$ Ovaj otpor može biti izražen u toj mjeri da dovede u pitanje odnos koji država članica ima s Unijom kao naddržavnom zajednicom. ${ }^{10}$ Pored toga, pojavljuje se čitav niz pitanja i dvojbi vezanih uz uspješnost, pa i budućnost europskog projekta. ${ }^{11}$

\subsection{Različiti tipovi integracija i različiti pristupi}

U posljednjih desetak godina više različitih kriza pogodilo je europski kontinent i države na njemu, neovisno o tome pripadaju li organizacijsko-politički euroatlantskim institucijama izraslima na poslijeratnom savezništvu zapadnih zemalja kao što su Europska unija ili pak NATO-savez. Svaka od država s tim se krizama borila na svoj način, sukladno vlastitim specifičnim društvenim, političkim

5 Usp. Petrić, D.: "The principle of Subsidiarity in the European Union: "Gobbledygook" Entrapped Between Justiciability and Political Scrutiny? The Way Forward", Zagrebačka pravna revija, god 6, br 3, 2017., str. 287-318.

6 O načinima na koje proces globalizacije utječe na suverenitet suvremenih država više u Lozina, D.: "Globalizacija i suverenitet nacionalne države", Zbornik radova Pravnog fakulteta u Splitu, god. 43, br. 1, 2006., str. 17-41.

7 Usp. Barton, O.: "An analysis of the principle of subsidiarity in European Union law", Nort East Law Review, god. 2, br. 1., 2014., str. 83-89.

8 Usp. Brandsma, G. J. - Hoppe, A.: "He who control the process controls the outcome? A reappraisal of the relais actor thesis", Journal of European Integration, Vol 43, br. 3., 2021., str. 347-363.

9 Usp. Ozlem Ultan, M. - Ornek, S.: "Euroscepticism in the European Union", International Journal of Social Sciences, Vol 4, No 2, 2015., pp. 49-57.

10 Usp. Gstöhl, S. - Phinnemore, D.: "The Future EU - UK partnership: a histiorical institutionalist perspective", Journal of European Integration, Vol. 43, br. 1, 2021., str. 99-115.

11 Bijsmans, P.: "The Eurozone crisis and Euroscepticism in the European press", Journal of European Integration, Vol 43, No. 3, str. 331-346. 
i gospodarskim okolnostima.U tom nastojanju da se potreškoće izazvane tim krizama uspješno prebrode, zemlje su bile više ili manje uspješne, te su specifičnim mehanizmima nastojale odgovoriti na tu razinu društvenog izazova s kojim su se suočile. Posebnu dimenziju u svladavanju nastalih problema i poteškoća dala je pripadnost Europskoj uniji, kao jednoj od ključnih euroatlantskih institucija za integraciju europskog kontinenta. Europska unija, kao savez europskih država trebao je osigurati integrativni institucionalni okvir za njihov društveni, politički i gospodarski razvoj. ${ }^{12}$ Dok je nastanak i organizacija NATO-saveza predstavljala u prvom redu stvaranje obrambene alijanse zapadnih nacija, zamišljena kao svojevrsni sigurnosni kišobran koji u konačnici olakšava i pojeftinjuje sustav obrane svake pojedine države, kroz organizaciju kolektivnog sustava sigurnosti, Europska unija od početka je zamišljena kao proces integracija koji bi trebao dovesti do konvergencije gospodarskih, upravnih i političkih sustava država članica. Pri tome je naglasak uvijek bio na stvaranju institucija koje trebaju osigurati provedbu zajedničkih europskih javnih politika. ${ }^{13}$ Daljnji korak bio je vertikalno povezivanje agencija koje reguliraju pojedina upravna područja na relaciji Europska unija - države članice, gdje se osigurava koordinacija između nacionalnih i europskih regulatora u oblikovanju europskih javnih politika. Postupno oblikovanje institucija Unije nastavlja se kroz proces izgradnje nadnacionalnog pravnog poretka uspostavljenog od strane država članica i Unije, koji dovodi do podijeljene nadležnosti između država članica i Unije u obavljanju pojedinih upravnih djelatnosti. ${ }^{14}$

Europska unija, kao projekt pomirenja i izgradnje zajedničke budućnosti europskih država i nacija, inicirana je i razvijana prvenstveno od strane Francuske i Njemačke. Njime je trebalo osigurati instituacionalni okvir za međusobno gospodarsko, društveno i političko uvezivanje zemalja europskog kontinenta, s

12 Usp. Garett, G.: "The Politics of Legal Integration in the European Union", International Organization, Vol. 49, No 1, 1995., str. 171-181.

13 U tom pogledu najvažnije je stvaranje mreže europskih agencija koje su zadužene za provedbu različitih javnih politika u nadležnosti Unije. U tom smislu Europske agencije slijede model tzv. agencifikacije, koji se očituje kroz izdvajanje upravnih i regulatornih poslova iz nadležnosti središnjih upravnih tijela i njihova povjeravanja institucijama osnovanima s ciljem obavljanja specifičnih stručnih upravnih poslova koje se želi zaštititi od izravnog utjecaja politike. Time se želi ostvariti autonomija i relativna neovisnost od strane političkih tijela glede njihova obavljanja, što posebno dolazi do izražaja unutar onih institucija, gdje se nastoji osigurati neovisnost stručnog djelovanja od upliva dnevno-političkih aktivnosti. Usp. Musa, A.: "Agencifikacija kao nova dodatna centralizacija - hoće li se Hrvatska ikad moći decentralizirati", Hrvatska i komparativna javna uprava, god. 12, br. 4, 2012., str. 1197-1224.

14 Ova karakteristika supranacionalnosti pravnog i upravnog poretka predstavlja inovativnu značajku i svojevrsnu alternativu između klasične podjele unutarnjeg javnog prava i klasičnog međunarodnog javnog prava. U tom smislu klasično međunarodno javno pravo više nije bilo primjenjivo na području nadležnosti Europskih zajednica, dok je nacionalno javno pravo trebalo biti zamijenjeno odredbama oblikovanima pod utjecajem europskog regulatornog okvira. S jačanjem procesa europskih integracija, razlikovanje između vanjske i unutarnje sfere upravno-političkog djelovanja države bilo je manje značajno. Javne ovlasti, ranije isključivo regalno pravo države, bivaju oblikovane u okviru zajedničkih europskih institucija, kao izravna posljedica okolnosti da same države članice mogu aktivno sudjelovati u njihovu oblikovanju, pa pristaju na podjelu nadležnosti u ovom pitanju. U tom smislu, raniji teritorijalno ograničeni sustav nacionalnog javnog prava otvara se u konvergenciji nacionalnih pravnih poredaka $u$ supranacionalni pravni poredak. Usp. Hofmann, H. C. H.: "Mapping the european administrative space", West European Politics, Vol. 31, 2008., br. 4., str. 662-676. 
Prof. dr. sc. Mirko Klarić: Treba li Europska unija upravno-politički ili političko-upravni pristup Zbornik radova Pravnog fakulteta u Splitu, god. 58, 3/2021, str. 711-727

ciljem izbjegavanja mogućih budućih teških sukoba i podjela u europskoj politici. ${ }^{15}$ Povijesni razvoj Europske unije tako započinje izgradnjom zajedničkih institucija i širenjem država koje se priključuju ideji izgradnje jedinstvene Europe. Njihovo širenje bilo je postupno, a dinamika proširenja ovisila je o specifičnim povijesnim okolnostima.

\subsection{Osnovne grupe koncepcijskih pitanja europske integracije: upravna i politička}

Od samog početka, ideja izgradnje zajedničkih europskih institucija otvarala je čitav niz koncepcijskih pitanja, koja se načelno mogu svesti na dvije osnovne grupe: upravna i politička. ${ }^{16}$ Upravna pitanja bavila su se izgradnjom integracijskih krugova koji su trebali osigurati ostvarivanje temeljnih sloboda na kojima počiva ideja Europe: sloboda kretanja ljudi, robe, usluga i kapitala. Ti su se integracijski krugovi kretali od izgradnje osnovnih institucija koje su trebale osigurati dinamiku ovih odnosa, te su uključivale izgradnju zajedničkog europskog tržišta. Na njemu je trebalo osigurati jednakopravnost pristupa svih, neovisno o tome iz koje europske zemlje sudionici dolazili. ${ }^{17}$ Daljnji integracijski krugovi trebali su dodatno olakšati i osigurati proces europskih integracija kroz jačanje zajedničkog tržišta. Ovi su se integracijski krugovi ogledali kroz stvaranje jedinstvenog šengenskog prostora kretanja ljudi te kroz stvaranje Europske monetarne unije. ${ }^{18}$ Paralelno s upravnim pitanjima, pojavljivala su se i politička pitanja, dobrim dijelom inicirana kroz implementaciju i rješavanje upravnih pitanja u intitucijama Europske unije. Ova su se pitanja bavila idejom samog europskog projekta i njegovom budućnošću. U

15 Usp. Dinan, D.: Europe Recast: A History of European Union, Lynne Rienner Publishers, 2014., str. 37-52.

16 Ova se pitanja javljaju kao pokušaj određivanja položaja i uloge Europske unije i njezinih institucija prema državama članicama koje je tvore s jedne, i drugim konkurentskim državnim političkoupravnim sustavima poput SAD-a, Kine, Indije ili Rusije s druge strane. Cinjenica je kako je proces europskih integracija dobrim dijelom iniciran upravo okolnošću da je jedino jedinstvena Europa dovoljno veliko područje da može pratiti uzastopne tehnološke revolucije, kao i primjenu suvremenih tehnologija u svakodnevnom životu. Pa i sama kriza prouzročena pandemijom COVID-a 19 pokazala je da se složeni tehnološki proizvodi poput cjepiva teško mogu razvijati bez svesrdne i obilne pomoći javnog sektora. S druge strane, nestašica medicinske opreme i drugog materijala u pandemiji pokazala je da su globalni lanci opskrbe iznimno krhki i da proces liberalizirane globalizacije u trenucima krize pokazuje velike slabosti, koje se posebno lome po manjim i slabije razvijenim državama. S druge strane, nastojanju da se kroz proces integracije i prijenos dijela suverenih ovlasti ostvare benefiti za države članice i njihove građane, suprotstavlja se suprotna težnja ka očuvanju samostalnosti i suverenosti nacionalnih država, koju obično prate rezerve glede realne izvedivosti snažnije integracije država na europskom kontinentu. O ulozi koju izgradnja zajedničkog europskog upravnog prostora ima na proces europskih integracije više u Kovač, P.: "Introduction to European Administrative Space as a Base for Spreading Standards and Builduing Capacities", u Koprić, I. - Kovač, P. (ed.): European Administrative Space: Spreading Standards, Building Capacities, NISPAcee, Bratislava, 2017., str. 9-19.

17 Usp. Koprić, I. - Musa, A. - Đulabić, V.: "Europski standardi regulacije službi od općeg interesa: (kvazi)nezavisna regulacijska tijela u izgradnji modernog kapitalizma", Hrvatska i komparativna javna uprava, Vol. 8, No 3, 2008., str. 647-688.

18 Usp. Szymanowsky, R.: "One step too far? The euro and European integration?", Journal of European Integration, Vol 42, br. 4., 2020., str. 601-608. 
osnovi političkih pitanja provlači se temeljna misao: više ili manje Europe, odnosno više ili manje europskih integracija i zajedničkih političkih institucija? ${ }^{19}$

Ovdje se mogu ogledati dva temeljna, oprečna i djelomično suprostavljena mišljenja po ovom pitanju. Prema jednom shvaćanju, Europska unija predstavlja zajednicu suverenih europskih država, koje se odriču dijela vlastitog suvereniteta kako bi osigurale niz benefita svojim građanima, poput slobode kretanja, ili pak zajedničkog nastupa prema trećima u međunarodnoj zajednici. ${ }^{20}$ Drugo shvaćanje uključuje doživljaj europskog projekta kao izgradnje naddržavnih institucija koje kroz širenje institucionalnih kapaciteta trebaju osigurati novu dimenziju naddržavne integracije na prostoru Europske unije. ${ }^{21}$ Ova dva shvaćanja od samog početka razvijaju se paralelno, i nužno ne isključuju jedan drugog.

\subsection{Upravno-političko shvaćanje europskih integracija}

Prvo shvaćanje u prvom je redu pragmatične prirode, jer polazi od zajedničkih interesa država članica, kao i benefita koje one ostvaruju zahvaljujući međusobnoj suradnji u izgradnji zajedničkih institucija. Koristi koje se ostvaruju veće su od ograničenja koje donosi članstvo, pa postoji nepodijeljeni interes da se Unija, kao zajednica suverenih država, očuva i dalje sinkronizirano razvija. S druge strane, nastojanje da se zajedničkim institucijama daje dublji smisao od podupiruće uloge u međusobnoj suradnji suverenih država članica, doživljava se s rezervom. Prema tom shvaćanju, Europa nije niti će biti Sjedinjene Europske Države, nego zajednica suverenih naroda i njihovih nacionalnih država.22 Ovakvo shvaćanje uključuje visoku razinu samostalnosti država članica prilikom donošenja važnijih političkih odluka na razini Unije. Uloga institucija Unije je koordinirajuća, a predloženi programi i javne politike imaju instruktivni karakter.

\subsection{Političko-upravno shvaćanje europskih integracija}

Drugo shvaćanje uključuje stvaranje i izgradnju svijesti o zajedničkom europskom identitetu, koji uz sve razlike treba postati polazišna točka za stvaranje zajedničkih

19 Usp. Coman, R. - Leconte, C.: "Contesting EU authority in the name of European Identity: the new clothes of the sovereignty discourse in Central Europe?", Journal of European Integration, Vol 41, 2019., br. 7, str. 855-870.

${ }^{20}$ Usp. Morillas, P.: "Autonomy in Intergovernmentalism: the role of de novo bodies in external action during the making of the EU Global Strategy", Journal of European Integration, Vol 42, br. 2, 2020., str. 231-246.

${ }^{21}$ Usp. Bellamy, R. - Kröger, S.: "A demoicratic justification of differentiated integration in a heterogeneous EU", Journal of European Integration, Vol. 39, br. 5., str. 625-639.

${ }^{22}$ O debatama vezanim uz shvaćanje suverenosti država članica, posebice u kontekstu izlaska Velike Britanije iz Europske unije više u Patberg, M.: "After the Brexit vote: what`s left of "split"popular sovereignty?", Journal of European Integration, Vol. 40, 2018, br. 7., str. 923-937. 
europskih institucija. ${ }^{23}$ Ove institucije trebaju osigurati integrativni okvir za čvršće političko i društveno povezivanje na europskom kontinentu, koje treba osigurati stabilnost političkih procesa, neovisno o društvenim i ekonomskim izazovima koji se pred institucijama pojavljuju. Ovako stvorene i oblikovane institucije trebaju biti podloga za snažniju integraciju država članica. ${ }^{24}$

Kao odraz ova dva shvaćanja, mogu se prikazati dva različita pristupa procesima europskih integracija: upravno-politički i političko-upravni. ${ }^{25}$ Ovi pristupi imaju sadržajno različita težišta, iako se njihovi učinci međusobno mogu preklapati. Upravno-politički pristup predstavlja upravno-tehničko djelovanje Europske unije kao zajednice suverenih država sa zajedničkim institucijama, koja svojim političkim i upravnim aktivnostima treba osigurati dodatne benefite svojim članicama i njihovim državljanima. Političko-upravni pristup predstavlja pogled na Europsku uniju kao proces izgradnje naddržavnih europskih institucija koje trebaju osigurati integrativne kapacitete i koheziju državnih politika te njihovu konvergenciju koja uključuje zajednički nastup prema drugim subjektima u međunarodnoj zajednici. Izgradnja tih institucija nije motivirana konkretnim dnevnim politikama ni problemima, ali je odraz svijesti da se oni ne mogu uspješno rješavati kroz postojeće institucije, bez dimenzije europske suradnje ili solidarnog jedinstva. ${ }^{26}$

23 O dihitomiji nacionalnog i europskog identiteta više u Harth, T.: "Zum Spannungsverhältnis zwischen nationaler und europäischer Identität", u Harth, T. - Schild, J. (ur.): Identität und Handlungsmöglichkeiten. Eine Deutsch - Französische Zukunfstwerkstatt für die politische Bildung, VS Verlag für Sozialwissenschaften, 2003., str. 29-40.

$24 \mathrm{O}$ društvenim aspektima i reperkusijama europskih integracija u svjetlu poslijeratnog razvoja europskih država i konvergencije njihovih gospodarskih, društvenih i političkih poredaka više u Riedeberger, A.: "Die EU zwischen einheitlicher und differenzierter Integration", Springer Fachmedien Weisbaden, 2016., str. 103-125.

25 Upravno-politički i političko-upravni pristup odražavaju dvije temeljne dimenzije koje oblikuju sve upravne procese. Jedna je tehnička, a druga interesna, a obje su važne kod sagledavanja organizacijskih aktivnosti u javnoj upravi. Tehnička dimenzija treba definirati načine obavljanja pojedinih upravnih djelatnosti, kao i procedure postupanja različitih javnih institucija u njihovu obavljanju. Tehnička dimenzija govori o načinu ostvarivanja proklamiranih političko-upravnih ciljeva i metodologiji koja se primjenjuje za njihovo ostvarivanje. Interesna dimenzija definira vrijednosti na kojima određeni upravno-politički sustav funkcionira. Ona u pravilu daje odgovor na pitanje u čijem se interesu obavljaju neke djelatnosti. Interesna dimenzija tako daje odgovor na pitanje čiji se interesi ostvaruju djelovanjem upravnog sustava, a čiji su interesi na šteti i zbog čega. Na ovaj tip pitanja teško se može pronaći izričit odgovor u formalnim dokumentima ili proklamiranim javnim aktima, ili su odgovori koji se iz njih mogu iščitati vrlo općeniti. Oni se obični zakrivaju interesima određenih društvenih skupina ili se pozivaju na opće interese društva ili države u danom trenutku. Bez interesne, političke dimenzije upravnog sustava, teško je definirati koji se primarni ciljevi žele ostvariti kroz tehničku dimenziju upravnog sustava, dok se tehnička dimenzija upravnog sustava ne može cjelovito sagledati bez interesne dimenzije. Usp. Pusić, E. i dr.: Hrvatska središnja državna uprava i usporedni upravni sustavi, Školska knjiga, Zagreb, 1999., str. 27-28.

26 Ovdje dolazi do izražaja pristup bottom-up, koji polazi od toga da je proces europeizacije iniciran procesima odozdo prema gore, pa je uloga viših razina upravljanja podređena nižim razinama u interakciji među različitim razinama javnog upravljanja. U tom smislu, jedno od temeljnih načela na kojima počiva organizacijsko ustrojstvo Unije jest načelo supsidijarnosti. Ono se izrijekom spominje u dokumentima Europske unije, prema kojima bi trebalo predstavljati samoograničavajuće sredstvo u vršenju ovlasti u područjima zajedničke nadležnosti. Sukladno tome, države članice samostalno djeluju na onim područjima na kojima mogu relativno uspješnije djelovati od institucija Unije. Ondje gdje institucije Unije mogu uspješnije djelovati, jer njihovi učinci nadilaze granice država članica, one bi trebale imati prvenstvo u svom djelovanju, a sukladno načelu supsidijarnosti. Usp. Bakota, B.: Problemi primjene načela supsidijarnosti, Pravni fakultet u Osijeku, Osijek, 2007., str. 61-63. 


\subsection{Upravno-politički pristup integracijama}

Upravno-političkim pristupom mogao bi se nazvati onaj pristup koji u sebi sadrži sintezu različitih upravnih politika koje uređuju pristup zajedničkom europskom tržištu, kao i međusobne odnose država članica. ${ }^{27}$ Ove politike odnose se na regulaciju temeljnih sloboda na kojima počiva Unija, i one se bave pitanjima prvenstveno upravno-tehničke prirode. Ta pitanja trebaju doprinijeti usklađivanju i harmonizaciji nacionalnih politika i njihovoj konvergenciji u zajednički upravni standard postupanja. ${ }^{28}$ Ove politike daju najčešće odgovor na pitanje kako nešto realizirati u cilju harmonizacije međusobnih odnosa među državama članicama Unije. ${ }^{29}$ Ovim se pitanjima bave različite Unijine upravne institucije, od Europske komisije do agencija Unije koje reguliraju pojedine segmente upravnog postupanja. ${ }^{30}$ Posebno se to odnosi na krovne regulatorne agencije koje imaju zadaću usklađivanja i osiguravanja jednakopravnosti tržišnog natjecanja na jedinstvenom europskom tržištu. To je od posebnog značaja kod reguliranja službi od općeg gospodarskog interesa, koje predstavljaju važan pokretač gospodarskog razvoja država članica Unije. Politika kreiranja i izgradnje zajedničkih europskih upravnih standarda predstavlja ključan čimbenik upravno-političkog pristupa.

Izgradnja zajedničkih upravnih standarda kao podloge za funkcioniranje institucija Unije i država članica, dovodi do stvaranja tzv. Europskog upravnog prostora, u kojem dolazi do konvergencije različitih upravnih politika, kao i standarda

27 Upravno-politički pristup predstavlja sastavni dio koncentracije moći i utjecaja koji imaju javne institucije u obavljanju različitih upravnih poslova, posebice u 20. stoljeću. Zbog toga toga općenito dolazi do povećanja utjecaja tijela javne vlasti u društvu, što otežava kontrolu nad djelovanjem javnih institucija, te potencijalno dovodi u pitanje ljudska i politička prava građana. Zbog negativnosti kritike nad koncentracijom moći i utjecaja u tijelima javne vlasti kao i u javnim institucijama, dolazi do tendencije prema dekoncentraciji upravnih sustava. Međutim, dekoncentraciju je teško provesti bez političkoupravnog okvira, koji treba redefinirati mogućnost demokratizacije odnosa po svim dimenzijama deregulacije, liberalizacije, sudjelovanja i suodlučivanja. Usp. Pusić, E.: Nauka o upravi, Školska knjiga, Zagreb, 2002., str. 116-118.

28 Valja istaknuti kako neprestano širenje digitalnih tehnologija i intenzivno komunikacijsko povezivanje snažno utječu na transformaciju političke vlasti i oblike javnog upravljanja u suvremenom društvu. Centralizacija informacija koju omogućava nova informacijska tehnologija otvara čitav niz pitanja poput prava privatnosti, informacijske sigurnosti ili mogućnosti nadzora javnih institucija od strane građana i drugih dionika civilnog društva. Političko-upravni pristup treba ponuditi novi integracijski okvir koji će ova pitanja i moderne izazove uklopiti, posebno u kontekstu odnosa između različitih razina javne odgovornosti: lokalne, nacionalne i nadnacionalne. Usp. Lozina, D.: Lokalna samouprava, Pravni fakultet Sveučilišta u Splitu, Split, 2004., str. 14-16.

${ }_{29}$ Usp. Chappel, L. - Exadaktylos, T. - Petrov, P.: "A more capable EU? Assesing the role of the EU's institutions in defence capability development", Journal of European Integration, vol. 42, br. 4. , 2020., str. 583-600.

30 Usp. Schmidt, V. A.: "Theorizing institutional change and governance in European responses to the Covid - 19 pandemic", Journal of European Integration, Vol. 42, br. 8., 2020., str. 1177-1193. 
postupanja. ${ }^{31}$ Europski upravni prostor nije formalno oblikovana institucija ili upravna doktrina, ali predstavlja teorijski okvir koji pomaže razumjeti približavanje nacionalnih upravnih politika i njihovu harmonizaciju sa standardima postupanja europskih institucija. Upravni standardi koji se definiraju kroz teorijski okvir Europskog upravnog prostora predstavljaju upravno-tehničku podlogu za upravnopolitički pristup, jer stavljaju naglasak na problematiku rješavanja konkretnih pitanja i provedbi zajedničkih europskih javnih politika. Zbog toga je pitanje upravno-političkog pristupa u prvom redu vezano uz rješavanje konkretnih pitanja i uređenje međusobnih pragmatičnih odnosa, kako među državama članicama, tako i unutar samih europskih institucija. I faktori koji otežavaju harmonizaciju Europskog upravnog prostora polaze od pragmatičnih odnosa koji prevladavaju među državama članicama. ${ }^{32}$

Ipak, ovakav pristup ne osigurava potrebnu količinu jedinstva, potrebnog za donošenje dugoročnih i dalekosežnih odluka, kao ni zajedničkih strategija. Njemu nedostaje politički okvir koji osigurava prostor za razvoj zajedničkih institucija i zajedničke politike, zbog naglaska na upravno-tehnička, a ne vrijednosno-politička pitanja. Sam politički okvir ostaje sporan, zbog nedostatka političkog jedinstva među državama članicama o tome u kojem pravcu treba usmeriti razvoj europskih institucija.

\subsection{Političko-upravni pristup integracijama}

Političko-upravni pristup predstavljao bi oblik institucionalnog i izvaninstitucionalnog angažmana koji uključuje izgradnju i jačanje zajedničkih političkih institucija Unije, koje bi trebale počivati na političkim vrijednostima i idejama, kao pokretačima gospodarskog, društvenog i kulturnog razvoja. Ovaj bi pristup trebao uključivati motive, interese i vrijednosti koje proaktivno utječu na razvoj europskih institucija i dinamiku odnosa među državama članicama. Za razliku od upravno-političkog pristupa, koji polazi od politički nespornih ali upravno-tehnički otvorenih pitanja, političko-upravni pristup polazi od političkih pitanja sadržajno prožetih etičkim principima i vrijednostima, što postavlja okvir

31 Europski upravni prostor u literaturi se određuje kao pravna stečevina na području javne uprave, koja nastaje uslijed proširenja Europske unije, a koja postavlja minimalne standarde što ih trebaju usvojiti države članice u procesu integracije svojih nacionalnih poredaka u jedinstveni institucionalni okvir Europske unije. Zbog toga države članice koje imaju različite pravne tradicije i političke sustave razvijaju zajedničku doktrinu, zajednička pravna načela i standardiziraju upravnu praksu kako bi osigurale jednoznačnu i efikasnu primjenu pravnih propisa. Usp. Musa, A.: Europski upravni prostor: približavanje nacuionalnih uprava, Javna uprava. Nastavni materijali, Društveno veleučilište u Zagrebu i Pravni fakultet u Zagrebu, Zagreb, 2005., str. 396-397.

32 Faktori koji otežavaju stvaranje Europskog upravnog prostora različite su upravne tradicije država članica, nedostatak sistemskog pristupa u rješavanju upravnih pitanja, problem provođenja upravnih reformi, koje uključuje čitav niz gospodarskih, političkih i društvenih pitanja, okolnost da su države članice autonomne u provođenju unutarnjih upravnih reformi te činjenicu kako su ovlasti i upravni kapaciteti Europske komisije ograničeni, pa ona djeluje prvenstveno putem relativno autonomnih agencija, dok je provedba prava Unije prepuštena javnim upravama država članica. Usp. isto, str. 402. 
za usmjeravanje i oblikovanje budućeg društvenog i gospodarskog razvoja. ${ }^{33}$ Upravno-tehnička pitanja relativno su nesporna, jer se bave pragmatičnim dnevnim temama koje osiguravaju normalan život i funkcioniranje društva, te harmonizaciju međusobnih odnosa država članica Unije. Političko-upravna pitanja otvaraju propitkivanje koncepta budućeg društvenog i gospodarskog razvoja, kao i vrijednosti na kojima treba počivati, pa shodno tome i razvoja političkih i upravnih institucija koje ga trebaju podržavati. Stoga se dinamika razvoja i funkcioniranja različitih institucija Unije treba promatrati kroz dinamku suprotnosti koju izazivaju potrebe društvenog razvoja s jedne, i procesi harmoniziranja tog razvoja s druge strane. Ova dinamika otvara čitav niz složenih i kompleksnih pitanja o funkcioniranju europskih institucija u kontekstu različitih izazova koji se danas nalaze pred Unijom i državama članicama. Političko-upravni pristup otvara pitanje legitimiteta političkih institucija Unije s jedne, i njihove sposobnosti da se nose sa sigurnosnim, financijskim i drugim društvenim izazovima s druge strane. ${ }^{34}$ Može se stoga reći kako su očekivanja od europskih institucija glede njihove učinkovitosti u rješavanju različitih političkoupravnih problema iznimno visoka, ali je istovremeno prisutna i značajna količina nepovjerenja prema njihovoj samostalnosti, neovisnosti i autonomnosti u odnosu na države članice Unije. ${ }^{35}$

Analizirajući razvoj institucija Unije, može se zamijetiti kako dolazi do promjene institucionalnog okoliša država članica i same Unije, što se može jednoznačno prikazati kroz stvaranje tzv. Europskog upravnog prostora, kao prostora konvergencije upravnih sustava država članica. Njegovo stvaranje kreira okvir koji dovodi do unificiranja zajedničkih obilježja u upravnim sustavima država članica. Sve to skupa dovodi do standardizacije upravnog postupanja kako država članica, tako i institucija same Unije. Kroz jačanje upravnog postupanja institucija Unije dolazi i do jačanja upravno-političkog pristupa u njezinu funkcioniranju.

33 Političko-upravni pristup pomaže oblikovati okvire budućeg političkog i društvenog razvoja različitih društvenih zajednica, od onih lokalnih, subnacionalnih, preko nacionalnih do nadnacionalnih zajednica. Istovremeno on definira i njihovu organizacijsku strukturu, koja je posebno važna kod ustrojstva državnih organizacija, ali isto tako i drugih oblika teritorijalnog organiziranja. Sama država predstavlja vrstu organizacije, a upravo je njezina organiziranost i organizacijska struktura osnova koja jamči njezinu akcijsku djelotvornost. Zbog toga je i državna vlast u prvom redu predstavljena smislenom, stalnom i sustavnom uporabom fizičke sile, a prijetnja njome temeljna je pretpostavka koja govori o organiziranosti države. Zbog toga i sam monopol organizirane fizičke sile u rukama državnog vodstva predstavlja potencijalni problem za društvo u kojem sama država, kao organizacija vlasti, djeluje. O tome više u Pusić, E.: Država i državna uprava, Pravni fakultet Sveučilišta u Zagrebu i Društveno veleučilište u Zagrebu, Zagreb, 2007., str. 12-15.

34 Dva su glavna izvora demokratske legitimacije europskih institucija u procesu odlučivanja. Prvi je supranacionalni, koji predstavlja Europski parlament. Drugi je nacionalno-državni, a predstavlja ga Vijeće sastavljano od nacionalnih reprezenata. O temeljima legitimiteta europskih institucija više u Bačić, A.: "O položaju, ulozi i značaju nacionalnog parlamenta u EU konstitucionalizmu", Zbornik radova Pravnog fakulteta u Splitu, god. 43, br. 2, 2006., str. 1-23.

35 Ovakav se stav često opisuje na način da se ukazuje kako su za sve uspjehe Unije zaslužne same države članice i njihove političke elite, a u slučaju neuspjeha isključiva se krivnja prebacuje na europske institucije i njihovu (ne)sposobnost za efikasno rješavanje problema, bilo da se radi o problemu imigracije, posljedicama financijske krize ili pak o različitim aspektima zdravstvene krize prouzročene zarazom koronavirusa. 
Upravno-politički pristup ne rješava temeljne političke napetosti u funkcioniranju Unije do kojih dolazi zbog nepostojanja neposrednih demokratskih političkih institucija, osim institucije Europskog parlamenta. Upravno-politički pristup rješava upravno-tehnička i praktična institucionalna pitanja, ali ne može rješiti ona pitanja koja počivaju na implementaciji političkih vrijednosti u provedbi javnih politika Unije. ${ }^{36}$ Kao poseban problem tu se pokazuje pitanje demokratskog deficita europskih institucija koje svoj mandat crpe iz instituta posredne demokracije. Sama institucija Europskog parlamenta nema dovoljnu snagu ni kapacitet da nametne smjer razvoja Unije kao naddržavne zajednice, iako dijeli legislativne ovlasti s Europskim vijećem. ${ }^{37}$ Ipak, one nisu dovoljne da bi se osigurali magistralni pravci razvoja Unije, kao zajednice suverenih europskih država. Druge institucije na razini Unije bez izravnog političkog legitimiteta crpe legitimitet iz institucija koje odražavaju nacionalnu politiku država članica, pa time i odražavaju njihove partikularne interese. ${ }^{38}$ Zbog toga se neka od gorućih pitanja vezana uz svakodnevno funkcioniranje Unije i njezinih institucija često guraju u drugi plan ako se ne može postići kompromisno rješenje koje bi zadovoljlo sve države članice. Ovakav pristup dovodi do podijeljenih stajališta o budućnosti europskih institucija i potrebi da se redefinira njihov međusobni odnos. Stoga pitanja koja generira upravno-politički pristup neminovno dovode do političko-upravnog razmatranja organizacijskih i političkih temelja na kojima počivaju institucije Unije i njihove ovlasti. S druge strane, političko-upravni pristup polazi od političkih okvira funkcioniranja Unije, a njegovo određivanje ovisi o konceptualnim pitanjima vezanima uz budući razvoj europskih institucija i uz dinamiku europskih integracijskih procesa. Problem s političko-upravnim pristupom očituje se u partikularnim interesima država članica i u nedostatku institucionalnih rješenja. Ovaj nedostatak proizlazi iz okolnosti da su se europske integracije u prvom redu razvijale kao upravno-politički projekt, s naglaskom na rješavanje konkretnih upravnih pitanja. Ta pitanja uključivala su izgradnju mehanizama zajedničkog tržišta, osiguranje njegovih temeljnih sloboda, a poslije i izgradnju drugog i trećeg kruga europskih integracija, kroz stvaranje Europske monetarne unije i Sengenske zone slobode kretanja. Iako se smatralo da su mehanizmi koji ih reguliraju relativno stabilni, neproturječni i čvrsti, kasniji izazovi, poput financijske krize iz prve dekade 21. stoljeća, i kasnije migrantske krize, doveli su do velikih problema u njihovu funkcioniranju. U tim je dihitomijama Europa pokušavala pravno-tehnički i upravno regulirati nastale probleme, mijenjajući pri

36 Upravno-tehnički pristup stoga otvara prostor razvoju i jačanju različitih suvremenih upravnih doktrina, koje djeluju u zajedničkom europskom institucionalnom prostoru, poput novog javnog menadžmenta ili pak dobre uprave. Iako je doktrina dobre uprave jedna od onih koje se smatraju ključnima, i doktrina novog javnog menadžmenta utječe, iako u manjoj mjeri, na oblikovanje političkih i upravnih institucija Unije. Usp. Hammerschmid, G. - Van der Walle, S. - Andrews, R. - Mostafa, A. M. S.: "New Public Management reforms in Europe and their effects: findigs from a 20-country executive survey", International Review of Administrative Sciences, Vol. 85, br. 3, 2019., str. 399-418.

37 Usp. Shoeller, M. G. - Héritier, A.: "Driving informal institutional change: the European Parliament and the reform of the Economic and Monetary Union", Journal of European Integration, Vol. 41, br. 3., 2019., str. 277-292.

38 Usp. Pérez - Durán, I. - Bravo-Laguna, C.: "Representative bureaucracy in European Union agencies", Journal of European Integration, Vol 41, br. 8., 2019., str. 971-992. 
tom postojeći integracijski okvir. Problem promjene integracijskog okvira Unije postao je pri tome posebno naglašen zbog nedostatka jedinstvenog stajališta o tome u kojem bi ga smjeru trebalo oblikovati.

\subsection{Integralni pristup}

Iako ne predstavlja državu, nego zajednicu država, Europska unija ima određena obilježja državnosti, koja se mogu promatrati s organizacijskog i s funkcionalnog aspekta. U organizacijskom smislu predstavlja skup različitih institucija s posebnim ovlastima za regulaciju različitih upravnih područja koja su joj prenesena u nadležnost. Sve te institucije imaju nadnacionalni karakter, ali se u provedbi svojih odluka oslanjaju na nacionalna upravna tijela. Ono što je razlikuje od samih država članica jest okolnost da su upravno-političke ovlasti kojima raspolažu njezine institucije prenesene od strane država članica. U funkcionalnom smislu, Unija obavlja niz poslova koji trebaju osigurati stabilan društveni i gospodarski razvoj njezinih država članica. Ipak, za razliku od svojih država članica, Unija nema izvorni nego preneseni suverenitet. Kao rezultat toga, i monopol fizičke prisile kojim raspolaže nije izvoran, nego je izveden i ovisi o implementaciji od strane njezinih država članica. Ipak, i putem prenesenog suvereniteta Unija obavlja niz upravnih funkcija za svoje članice, doprinoseći tako stvaranju zajedničkih upravnih standarda. Oni se nastoje jasnije odrediti kroz oblikovanje različitih teorija europskog upravljanja, od kojih su najznačajnije liberalni intergovernmentalizam, nadnacionalno upravljanje te višerazinsko upravljanje. ${ }^{39}$

Upravni aspekti europskih integracija mogu se promatrati kroz procese koji se odvijaju vertikalno i horizontalno. Vertikalni pristup odvija se kroz top-down i bottom-up pristup u interakciji subnacionalnih, nacionalnih i europskih institucija. Horizontalni pristup može se promatrati u interakciji različitih europskih institucija koje osiguravaju zajednički regulatorni okvir za ostvarivanje interesa država članica kao i prava njihovih građana. Zbog toga se, radi cjelovitog sagledavanja uloge koju imaju Europska unija i njezine institucije, funkcioniranje Unije treba promatrati integralno, kroz oba pristupa, jer se jedino tako može razumjeti dinamika upravnih i političkih procesa koji osiguravaju konvergenciju upravno-političkih i gospodarskih sustava država članica. Zbog toga su oba pristupa - i političko-upravni i upravno-

39 Liberalni intergovernmentalizam tvrdi da europske integracije jačaju države i njihove nacionalne egzekutive, pa se time nužno ne isključuje uloga koju imaju države članice u europskim integracijama. S druge strane, teorija nadnacionalnog upravljanja smatra da europska integracija stvara novu višerazinsku politiku promjenom načina na koji domaći akteri odgovaraju na integraciju. U središtu su takvog pristupa multinacionalne korporacije koje djeluju izvan granica nacionalnih država, pa je naglasak na regulaciji pojedinih upravnih sektora. Time dolazi do izražaja okolnost da europske institucije reguliraju ciljano ona područja u kojima raspolažu prenesenim ovlastima. Višerazinsko upravljanje pak ističe kako europske integracije utječu na promjenu odnosa javne i privatne sfere, kao i na sam karakter nacionale države. Njega odlikuje veće sudjelovanje nevladinih aktera, sudjelovanje različitih teritorijalnih stupnjeva u procesu javnog odlučivanja te transformacija uloge države u smjeru zaštite i jačanja njezine autonomije prema europskim institucijama. Usp. Koprić, I. - Musa, A. - Lalić Novak, G.: Europski upravni prostor, Institut za javnu upravu, Zagreb, 2012., str. 60-63. 
politički - važna, jer predstavljaju svojevrsnu dijalektiku razvoja europskih odnosa. ${ }^{40}$ Upravno-politički pristup stvara empirijsku podlogu za razvoj europskog političkoupravnog modela koji treba osigurati daljnju konvergenciju političkih i upravnih sustava država članica. Političko-upravni model kroz zajedničke političke i upravne institucije te sinkronizirani regulatorni okvir stimulira dalji razvoj zajedničkih europskih javnih politika, koje utječu na ukupan gospodarski društveni razvoj kako država članica, tako i Unije u cjelini.

\section{ZAKLJUČAK}

Predmet ovog rada bila je analiza dvaju temeljnih pristupa u procesu europskih integracija: političko-upravnog i upravno-političkog, kao odraza dvaju različitih shvaćanja europskih integracija. Političko-upravni pristup ima težište na razvoju i jačanju europskih institucija, kao i na izgradnji posebnog regulatornog okvira, koji treba osigurati jedinstveni pristup rješavanju zajedničkih problema država članica Unije. Upravno-politički pristup težište stavlja na rješavanje praktičnih gospodarskih i društvenih pitanja putem zajedničkih europskih institucija i uz suradnju s upravnim i političkim institucijama država članica, koja se ostvaruje zahvaljujući među ostalim i procesu konvergencije upravnih sustava država članica. Iako su po obuhvatu različiti, oba su pristupa značajna za dinamiku razvoja europskih institucija. Političko-upravni pristup polazi od stvaranja i jačanja zajedničkih institucija nužnih za kreiranje zajedničkih javnih politika, jedinstveno postupanje u rješavanju različitih upravnih problema, kao i zajednički nastup prema trećim zemljama. S druge strane, ovaj pristup dovodi do sužavanja prostora autonomije država članica i samostalnosti u njihovu postupanju. Upravno-politički pristup stavlja naglasak na konvergenciju upravnih sustava, koja se ogleda kroz usvajanje zajedničkih standarda postupanja, u provedbi različitih upravnih politika, uređenju pojedinih područja djelovanja i općenito rješavanju praktičnih pitanja. Ovakav pristup ne pridonosi stvaranju zajedničkog institucionalnog okvira, nužnog za stvaranje i provedbu jedinstvenih javnih politika.

Specifičnosti u primjeni jednog i drugog pristupa rezultat su okolnosti u kojima su se europske integracije odvijale. Europska unija, za razliku od drugih državnih i političkih zajednica, ima specifičan povijesni i politički razvoj pa njezine članice inzistiraju na visokom stupnju samostalnosti i neovisnosti u donošenju različitih političkih odluka. Istovremeno, suvremeni gospodarski i društveni razvoj, kao i proces globalizacije, utječu na potrebu snažnijeg povezivanja država članica, pa i po cijenu gubitka dijela samostalnosti u donošenju političkih odluka. Ovo s druge strane otvara niz novih pitanja vezanih uz položaj i ulogu država članica unutar Unije, poput ideje o Europi više brzina, gdje bi se dolazilo do snažnijeg povezivanja onih država koje to žele, dok bi druge zadržale postojeći političko-

40 O višerazinskom pristupu koji uključuje više razina javnog upravljanja i razvoja zajedničkih javnih politika u samoj Uniji - europsku, državnu i regionalnu - više u von Krause, U.: "Mehrebenengovernance in der EU", VS Verlag für Sozialwissenschaften, Springer, 2008., str. 11-30. 
upravni okvir. Upravo se mogućnost realizacije ideje o Europi više brzina nameće kao kompromisno rješenje za harmonizaciju različitih shvaćanja o europskim integracijama, kao i o položaju i ulozi država članica u njima. Time se omogućuje i stimulira stvaranje integralnog pristupa koji bi objedinio elemente i političkoupravnog i upravno-političkog pristupa u procesu izgradnje europskih institucija, jer bi se omogućili snažniji procesi integracija onim državama članicama koje to žele, uz istovremeno poštovanje postojećeg integracijskog modela za one države članice koje inzistiraju na većem stupnju samostalnosti i suverenosti u donošenju političkih odluka i obavljanju upravnih poslova. Zbog toga samo pitanje koji pristup odabrati ovisi u prvom redu o specifičnim interesima svake države članice, te u ovom trenutku predstavlja više individualno pitanje, a ne nekakav generalni stav o tome u kojem smjeru treba očekivati razvoj europskih institucija kao i međusobne odnose članica Unije.

\section{IZVORI:}

1. Bačić, A.: "EU ante portas i Ustav Republike Hrvatske", Zbornik radova Pravnog fakulteta u Splitu, god. 38, 2001., str. 259-281.

2. Bačić, A.: "O položaju, ulozi i značaju nacionalnog parlamenta u EU konstitucionalizmu", Zbornik radova Pravnog fakulteta u Splitu, god. 43, br. 2, 2006. str. 1-23.

3. Bakota, B.: Problemi primjene načela supsidijarnosti, Pravni fakultet u Osijeku, Osijek, 2007.

4. Barton, O.: "An analysis of the principle of subsidiarity in European Union law", Nort East Law Review, god. 2, br. 1., 2014., str. 83-89.

5. Bellamy, R. - Kröger, S.: "A demoicratic justification of differentiated integration in a heterogeneous EU", Journal of European Integration, Vol. 39, br. 5., str. 625-639.

6. Bijsmans, P.: "The Eurozone crisis and Euroscepticism in the European press", Journal of European Integration, Vol 43, No. 3, str. 331-346.

7. Brandsma, G. J. - Hoppe, A.: "He who control the process controls the outcome? A reappraisal of the relais actor thesis", Journal of European Integration, Vol 43, br. 3., 2021., str. 347-363.

8. Chappel, L. - Exadaktylos, T. - Petrov, P.: "A more capable EU? Assesing the role of the EU's institutions in defence capability development", Journal of European Integration, vol. 42, br. 4., 2020., str. 583-600.

9. Coman, R. - Leconte, C.: "Contesting EU authority in the name of European Identity: the new clothes of the sovereignty discourse in Central Europe?", Journal of European Integration, Vol 41, 2019., br. 7, str. 855-870.

10. Dinan, D.: Europe Recast: A History of European Union, Lynne Rienner Publishers, 2014., str. 37-52.

11. Eichorn, J. - Kenealy, D. - Hübner, C.: "Who wants a referndum on EU membership? Exploring public attitudes in six Member States", Journal of European Integration, Vol. 43, br. 3., 2021., str. 365-383. 
Prof. dr. sc. Mirko Klarić: Treba li Europska unija upravno-politički ili političko-upravni pristup Zbornik radova Pravnog fakulteta u Splitu, god. 58, 3/2021, str. 711-727

12. Garett, G.: "The Politics of Legal Integration in the European Union", International Organization, Vol. 49, No 1, 1995., str. 171-181.

13. Gstöhl, S. - Phinnemore, D.: "The Future EU - UK partnership: a histiorical institutionalist perspective", Journal of European Integration, Vol. 43, br. 1, 2021., str. 99-115.

14. Hammerschmid, G. - Van der Walle, S. - Andrews, R. - Mostafa, A. M. S.: "New Public Management reforms in Europe and their effects: findigs from a 20-country executive survey", International Review of Administrative Sciences, Vol. 85, br. 3, 2019., str. 399-418.

15. Harth, T.: "Zum Spannungsverhältnis zwischen nationaler und europäischer Identität", u Harth, T. - Schild, J. (ur.): Identität und Handlungsmöglichkeiten. Eine Deutsch - Französische Zukunfstwerkstatt für die politische Bildung, VS Verlag für Sozialwissenschaften, 2003., str. 29-40.

16. Hofmann, H. C. H.: "Mapping the european administrative space", West European Politics, Vol. 31, 2008., br. 4., str. 662-676.

17. Koprić, I. - Musa, A. - Đulabić, V.: "Europski standardi regulacije službi od općeg interesa: (kvazi)nezavisna regulacijska tijela u izgradnji modernog kapitalizma", Hrvatska i komparativna javna uprava, Vol. 8, No 3, 2008., str. 647-688.

18. Koprić, I. - Musa, A. - Lalić Novak, G.: Europski upravni prostor, Institut za javnu upravu, Zagreb, 2012.

19. Kovač, P.: "Introduction to European Administrative Space as a Base for Spreading Standards and Builduing Capacities", u Koprić, I. - Kovač, P. (ed.): European Administrative Space: Spreading Standards, Building Capacities, NISPAcee, Bratislava, 2017., str. 9-19. von Krause, U.: "Mehrebenengovernance in der EU", VS Verlag für Sozialwissenschaften, Springer, 2008.

20. Lopatka, R.: "Subsidiarity: Bridging the gap between the ideal and reality", European View, god. 18, br. 1., 2019., str. 26-36.

21. Lozina, D.: "Globalizacija i suverenitet nacionalne države", Zbornik radova Pravnog fakulteta u Splitu, god. 43, br. 1, 2006., str. 17-41.

22. Lozina, D.: Lokalna samouprava, Pravni fakultet Sveučilišta u Splitu, Split, 2004.

23. Morillas, P.: "Autonomy in Intergovernmentalism: the role of de novo bodies in external action during the making of the EU Global Strategy", Journal of European Integration, Vol 42, br. 2, 2020., str. 231-246.

24. Musa, A.: "Agencifikacija kao nova dodatna centralizacija - hoće li se Hrvatska ikad moći decentralizirati", Hrvatska i komparativna javna uprava, god. 12, br. 4, 2012. str. 1197-1224.

25. Musa, A.: Europski upravni prostor: približavanje nacuionalnih uprava, Javna uprava. Nastavni materijali, Društveno veleučilište u Zagrebu i Pravni fakultet u Zagrebu, Zagreb, 2005.

26. Ozlem Ultan, M. - Ornek, S.: "Euroscepticism in the European Union", International Journal of Social Sciences, Vol 4, No 2, 2015., pp. 49-57. 
Prof. dr. sc. Mirko Klarić: Treba li Europska unija upravno-politički ili političko-upravni pristup Zbornik radova Pravnog fakulteta u Splitu, god. 58, 3/2021, str. 711-727

27. Patberg, M.: "After the Brexit vote: what's left of "split" popular sovereignty?", Journal of European Integration, Vol. 40, 2018, br. 7., str. 923-937.

28. Pérez - Durán, I. - Bravo-Laguna, C.: "Representative bureaucracy in European Union agencies", Journal of European Integration, Vol 41, br. 8., 2019., str. 971-992.

29. Petrić, D.: "The principle of Subsidiarity in the European Union: "Gobbledygook" Entrapped Between Justiciability and Political Scrutiny? The Way Forward", Zagrebačka pravna revija, god 6, br 3, 2017., str. 287-318.

30. Pusić, E.: Država i državna uprava, Pravni fakultet Sveučilišta u Zagrebu i Društveno veleučilište u Zagrebu, Zagreb, 2007.

31. Pusić, E. i dr.: Hrvatska središnja državna uprava i usporedni upravni sustavi, Školska knjiga, Zagreb, 1999.

32. Pusić, E.: Nauka o upravi, Školska knjiga, Zagreb, 2002.

33. Riedeberger, A.: "Die EU zwischen einheitlicher und differenzierter Integration", Springer Fachmedien Weisbaden, 2016., str. 103-125.

34. Schmidt, V. A.: "Theorizing institutional change and governance in European responses to the Covid - 19 pandemic", Journal of European Integration, Vol. 42, br. 8., 2020., str. 1177-1193.

35. Shoeller, M. G. - Héritier, A.: "Driving informal institutional change: the European Parliament and the reform of the Economic and Monetary Union", Journal of European Integration, Vol. 41, br. 3., 2019., str. 277-292.

36. Szymanowsky, R.: "One step too far? The euro and European integration?", Journal of European Integration, Vol 42, br. 4., 2020., str. 601-608.

\section{DOES THE EUROPEAN UNION NEED ADMINISTRATIVE- POLITICAL OR POLITICAL-ADMINISTRATIVE APPROACH}

The paper analyses two different conceptual approaches in the development of political and administrative institutions in context of integration processes in European Union: administrativepolitical and political-administrative approach. It starts from different concepts of the role that European integration has for Member States, in order to point out the implications of different approaches to integration processes at the Union level. The first part of the research sets out a methodological framework for analysis these two approaches and their impact on European integration. The second part is dedicated to the analysis of the results related to the application of these approaches. Their implementation is monitored through the process of convergence of the administrative systems of the Member States, as well as political-conceptual differences related to their implementation. In the last part of this article, through concluding remarks, it is presenting assessment of these approaches in current development of European institutions and their impact on the future development of integration processes in the European Union.

Key words: European Union, political-administrative approach, administrative-political approach 